\title{
ANALISIS PERLAKUAN AKUNTANSI ATAS PENGELOLAAN BERAS SEJAHTERA PADA PERUM BULOG DIVRE SULAWESI UTARA DAN GORONTALO
}

\author{
Veronika Merlin Imbang ${ }^{1}$, Winston Pontoh $^{2}$, Hendrik Gamaliel $^{3}$ \\ 1,2,3 Jurusan Akuntansi, Fakultas Ekonomi dan Bisnis, Universitas Sam Ratulangi, Jl.Kampus Bahu, Manado, \\ 95115, Indonesia \\ E-mail : v.imbang28@yahoo.com
}

\begin{abstract}
The Beras Sejahtera (Rastra), a program that assisted by government, has been working with Public Enterprise Logistics Company (Perum Bulog) in an attempt to improve food security as well as provide protection for underprivileged communities. This research aims to know the accounting of the management of the Beras Sejahtera at Perum Bulog Divre North Sulawesi and Gorontalo. The methods used in this research is descriptive method and qualitative research. This research obtained that the accounting of the management of the Beras Sejahtera at Perum Bulog Divre North Sulawesi and Gorontalo is using accrual-based and the reports are already organized in the regulation of Director Of Public Companies On Accounting Policy in Perum Bulog.

Keywords: Analysis, Accounting, Beras Sejahtera
\end{abstract}

\section{PENDAHULUAN}

Perkembangan dunia yang semakin modern serta dunia usaha yang ikut bertumbuh mengakibatkan meluasnya jaringan perusahaan yang berdiri diberbagai bidang kegiatan yang berskala nasional maupun internasional sektor publik serta swasta. Pemerintah pusat dan daerah terus bekerja sama dalam membangun kesejahteraan masyarakat dengan menyediakan dan memfasilitasi keperluan seluruh warga negara serta membantu dibidang ekonomi, infrasturktur terlebih ketahanan pangan. Indonesia saat ini masih mengalami krisis ekonomi dan masalah kemiskinan dan rawanan pangan, krisis yang menekan perekonomian Indonesia pada pertengahan tahun 1997 memberi dampak yang sangat merugikan bagi kondisi ekonomi secara keseluruhan dan yang paling berpengaruh yaitu pada kesejahteraan masyarakat (Basuki 2013 : 87-88).

Memenuhi kebutuhan masyarakat dalam bidang pangan yaitu beras, pemerintah dapat terpacu agar bisa menebus perangkap kemiskinan yang melekat pada dirinya sehingga dapat mengurangi jumlah masyarakat miskin. Salah satunya yaitu dengan mengadakan program bantuan dari pemerintah seperti menyediaan dan pengadaan serta penyaluran beras yang dikhususkan bagi keluarga yang memiliki ekonomi menengah ke bawah dengan mengadakan bantuan beras untuk keluarga miskin yang saat ini berahli menjadi Beras Sejahtera (Rastra) yang dilaksanaan di bawah tanggung jawab Departement Dalam Negeri dan Perusahaan Umum Badan Usaha Logistik (Perum Bulog) sesuai dengan Surat Keputusan Bersama (SKB) Menteri Dalam Negeri dengan Direktur Utama Perum Bulog Nomor 25 Tahun 2003 dan nomor PKK-12/07/2003, serta melibatkan Instansi terkait, Pemerintah dan masyarakat yang diatur dalam Peraturan Presiden Republik Indonesia Nomor 48 tahun 2016 tentang Penugasan Kepada Perum Bulog, yang tugas utamanya menjaga harga dasar pembelian gabah, stabilisasi harga pokok, menyediakan dan menyalurkan beras sejahtera serta mengelolah stok pangan. Ruang lingkup bisnis perusahaan meliputi usaha logistik/pergudangan, survei dan pemberantasan hama, penyediaan karung plastik, usaha angkutan, perdagangan komoditi pangan dan usaha eceran (Bulog, 2018). 
Program Raskin (Beras untuk keluarga miskin) yang sekarang ini berahli menjadi program beras sejahtera (Rastra) adalah program yang bersentuhan langsung dengan masyarakat dan membantu masyarakat dengan mengurangi beban pembelian rumah tangga melalui penyediaan beras bersubsidi. Program ini pada dasarnya merupakan kelanjutan dari program Operasi Pasar Khusus (OPK) yang diluncurkan pada bulan Juli 1998. Progam Rastra ini bertujuan untuk mengurangi beban pengeluaran bagi masyarakat yang kurang mampu sebagai suatu bentuk dukungan dalam meningkatkan ketahanan pangan dengan memberi perlindungan sosial beras murah dengan subsidi pemerintah (Ganuwiara $2018: 3$ ).

Pelaksanaan program beras sejahtera sering kali terdapat didalamnya masalah, adapun berbagai masalah yang terjadi dalam proses penyaluran beras sejahtera. Permasalahan yang ada, terjadi dinilai dari berbagai proses, mulai dari proses pendistrubusian, beras rastra tidak sampai ke KPM (Keluarga Penerima Manfaat), Pagu rastra yang kadang lama dikeluarkan, surat perintah alokasi lama diajukan ke bulog dan tidak tepat waktu penerimaan beras sejahtera kepada rumah tangga penerima manfaat, serta salah sasaran yang disebabkan dari orang-orang atau kelompok tim kerja yang telah ditugaskan. Petugas lapangan yang masih memengang prinsip kekeluargaan yang nanti nya dibagikan hanya kepada anggota keluarganya, kerabat atau orang dekatnya. Pembagian beras bersubsidi pun tidak sedikit yang menerimanya dari kalangan yang bukan miskin tetapi kelurga yang berpendapatan lebih dengan kata lain bahwa beras sejahtera lebih banyak diterima oleh rumah tangga bukan miskin. Banyak rumah tangga sejahtera yang mendapat beras sejahtera padahal rumah tangga tersebut mampu mencukupi kebutuhannya dan permasalahan yang sering terjadi dalam proses pencatatan herga tebus rastra (HTR), kendala yang terjadi pada saat penyetoran HTR biasanya orang yang menyetor lupa mencantumkan nama desa, sering juga penyetor membayar dengan menyicil jadi menyulitkan bagian akuntansi dalam pencatatan (Bulog, 2013).

Melalui program ini pemerintah memberikan bantuan kepada masyarakat miskin hak atas pangan dan tujuan untuk mengurangi beban pengeluaran rumah tangga sasaran melalui pemenuhan sebagai kebutuhan pangan beras. Peraturan Menteri Keuangan Nomor 125/PMK.02/2010 tentang Subsidi beras bagi masyarakat berpendapatan rendah, subsidi beras merupakan suatu program penanggulangan kemiskinan yang termaksud dalam program bantuan sosial berbasis keluarga yang sudah berjalan secara rutin sejak tahun 1998 (MenKeu).

\section{TINJAUAN PUSTAKA}

\subsection{Pengertian Akuntansi}

Akuntansi adalah suatu seni pencatatan, penggolongan, dan peringkasan dengan cara yang informatif dan diukur dalam bentuk mata uang, atas transaksi-transaksi atau kejadiankejadian keuangan perusahaan dan interpretasi hasilnya (Tanor, 2015). Akuntansi menyangkut seluruh proses pelaporan yang dimulai dari pengidentifikasian transaksi bisnis, pencatatan, perkomunikasian (dalam bentuk laporan), sampai pada tahapan analisis dan interpretasi (Hery, 2013 : 8). Tujuan akuntansi secara keseluruhan adalah memberikan informasi yang dapat digunakan dalam pengambilan keputusan (Tinungki, 2014).

\subsection{Akuntansi Sektor Publik}

Akuntansi sektor publik adalah jasa yang terdiri dari mencatat, mengklasifikasikan dan melaporkan kejadian atau transaksi ekonomi yang akhirnya akan menghasilkan suatu informasi keuangan yang akan dibutuhkan oleh pihak-pihak tertentu untuk pengambilan keputusan yang diterapkan pada pengelolaan dana publik di lembaga-lembaga tinggi negara dan departemen-departemen di bawahnya (Wiratna, 2015).

\subsection{Pengertian Standar Akuntansi Pemerintahan}

Peraturan Pemerintah No.71 Tahun 2010 yang menjelaskan tentang Standar 
Akuntansi Pemerintahan menyatakan bahwa akuntansi merupakan proses pengidentifikasian, pencatatan, pengukuran, pengklasifikasian, pengikhtisaran transaksi dan kejadian keuangan, penyajian laporan serta menginterpretasikan hasilnya. Standar Akuntansi Pemerintahan merupakan prinsip akuntansi yang diterapkan untuk melakukan penyusunan dan penyajian laporan keuangan pemerintah, yang terdiri dari Laporan Keuangan Pemerintah Pusat (LKPP) dan Laporan Keuangan Pemerintah Daerah (LKPD) dalam rangkan transparansi dan akuntabilitas penyelenggaraan akuntansi pemerintah, serta meningkatkan kualitas LKPP dan LKPD.

\subsection{Perlakuan Akuntansi}

Menurut Rahman (2013 : 25) ada beberapa konsep yang terkait dengan perlakuan akuntansi, yaitu diantaranya:

1. Konsep Pengakuan

Pengakuan dalam akuntansi adalah sebuah proses penetapan terpenuhi kriteria pencatatan suatu kejadian atau peristiwa dalam pencatatan akuntansi, sehingga kejadian atau peristiwa dalam itu akan menjadi bagian yang melengkapi unsur aset, kewajiban, ekuitas, pendapatan dan beban sebagaimana akan termuat pada laporan keuangan dari entitas pelaporan yang bersangkutan.

2. Konsep Pengukuran/Penilaian

Pengukuran dalam akauntansi adalah sebuah proses penempatan nilai uang demi mengakui dan memasuakan setiap pos pada laporan keuangan. Pengukuran terhadap pospos laporan keuangan menggunakan mata uang rupiah.

3. Konsep Penyajian

Penyajian dalam akuntansi adalah sebuah proses penempatan suatu akun secara terstruktur pada laporan keuangan. Akun aset, kewajiban dan ekuitas (akun rill) disajikan dalam laporan neraca, sedangkan akun pendapatan dan beban (akun nominal) disajikan dalam laporan laba rugi.

4. Konsep Pengungkapan

Pengungkapan dalam akuantansi adalah sebuah proses penjelasan naratif atau rincian menyangkut angka-angka yang tertera dalam laporan neraca, laporan laba rugi dan laporan arus kas.

\subsection{Program Beras Sejahtera (Rastra)}

\subsubsection{Pengertian dan Penjelasan Program Rastra}

Program Rastra (Beras sejahtera) adalah sebuah program bantuan dari pemerintah yang bekerja sama dengan Perusahaan Umum Badan Usaha Logistik (Perum Bulog) dalam upaya meningkatkan ketahanan pangan serta memberikan perlindungan bagi keluarga kurang mampu atau tergolong masyarakat berpendapatan menengah kebawah melalui program beras sejahtera yang di distribusikan dalam jumlah dan harga tertentu atau yang sudah menjadi kesepakatan antara beberapa pihak. Program ini juga bertujuan untuk mengatasi masalah kemiskinan, dengan maksud dengan mengurangi beban pengeluaran rumah tangga miskin serta membantu masyarakat mendapat beras untuk kebutuhan pangan rumah tangganya (Sumber: Buku Pedoman Umum Subsidi Rastra 2017).

\subsubsection{Tujuan dan Sasaran Program Rastra}

Program beras sejahtera memiliki tujuan untuk mengurangi beban pengeluaran rumah tangga yang miskin melalui pemenuhan sebagian kebutuhan pangan yang dalam hal ini beras, serta sasaran dari program beras sejahtera adalah untuk meningkatkan akses masyarakat yang kurang mampu dalam memnuhi kebutuhan pokok dalam rangka menguatkan ketahanan pangan sebagai salah satu hak dasar masyarakat. Program rastra bekerja sama dengan pemerintah pusat maupun daerah, yang menjadi salah satu program yang sangat penting (Sumber: Buku Pedoman Umum Subsidi Rastra 2017). 


\subsection{Dasar Penangihan Dari Perum Bulog}

1. Sebelum menyampaikan tagihan, Perum Bulog wajib menyampaikan Surat pemberitahuan Perencanaan Tagihan.

2. Penagihan disampaikan oleh Perum Bulog setiap bulan.

3. Penagiahan disampaikan dengan melampirkan:

a. Surat Penagihan Penyaluran (SPP) dari Kementerian Sosial Kepada Perum Bulog.

b. Dokumen DPM Bansos Rastra.

c. SPPB/DO.

d. Rekapitulasi BAST

e. Surat tagihan yang ditanda tangani Direktur Utama Perum Bulog.

f. Surat Pernyataan Tanggung Jawab Mutlak Direktur Utama Perum Bulog yang dibuat berdasarkan Surat Pernyataan Pertanggungjawaban Pemda Kab/kota.

g. Surat pernyataan kebenaran dokumen.

h. Surat pernyataan bersedia diperiksa ulang.

i. Kuitansi sejumlah tagihan pada masing-masing rekening Perum Bulog.

\subsection{Indikator Keberhasilan Rasta}

Dalam Pedoman Umum Rastra, menyatakan implementasi distribusi rastra harus mengacu pada indikator keberhasilan rastra yaitu terger 6T (Enam Tepat) tepat sasaran penerima, Tepat jumlah, Tepat harga, Tepat waktu, Tepat kualitias dan Tepat administrasi (Sumber: Buku Pedoman Umum Subsidi Rastra 2017).

\section{8. $\quad$ Subsidi}

Subsidi adalah salah satu kebijakan dari pemerintah dalam memberi perlindungan dan bantuan pada industri dalam negeri dengan bentuk seperti keringanan pajak, pengembalian pajak, fasislitas kredit, subsidi harga dan lain sebagainya untuk menambah produksi dalam negeri, mempertahankan jumlah konsumsi dalam negeri serta menjual dengan harga yang lebih murah dari pada produk impor.

\subsection{Pelaporan dan Pertanggung jawaban}

1. Pelaksana Distribusi Rastra melaporkan pelaksanaan Program Rastra pada Tim Koordinasi Rastra Kecamatan secara periodik setiap bulannya.

2. Tim Koordinasi Rastra Kecamatan melaporkan pelaksanaan Program Rastra pada Tim Koordinasi Rastra Kabupaten/Kota secar periodik setiap bulannya.

3. Tim Koordinasi Rastra Kabupaten/Kota melakukan pelaporan pelaksanaan Program Rastra pada Tim Koordinasi Rastra Provinsi secara periodik setiap triwulan, dengan membuat tembusan kepada sekretaris TKPK di kabupaten/kota setempat.

4. Tim Koordinasi Rastra Provinsi melaporkan pelaksanaan Program Rastra pada Menteri Koordinator Bidang Pembangunan Manusia dan Kebudayaan, Menteri Koordinator Bidang Perekonomian, Menteri Sosial, Menteri Dalam Negeri dan Tim Koordinasi Rastra Pusat, dengan tembusan pada sekretaris TKPK Provinsi setempat, secara periodik setiap Semester.

5. Laporan Akhir dari Pelaksanaan Program Rastra dibuat oleh Tim Koordinasi Rastra Pusat, Provinsi, serta Kabupaten/Kota pada akhir tahun.

6. Perum BULOG melaporkan pelaksanaan pendistribusian Rastra pada Ketua Tim Koordinasi Rastra Pusat dan Kuasa Pengguna Anggaran (KPA) setiap bulannya.

7. Lokasi TD dan TB serta perubahan/pemutakhirannya dilaporkan oleh Tim Koordinasi Rastra Kabupaten/Kota pada Tim Koordinasi Rastra Pusat, dengan membuat tembusan kepada Tim Koordinasi Rastra Provinsi.

8. Dokumen BA Mudes/Muskel/Muscam, FRP dan FPPDT-PFM dilaporkan oleh Kabupaten/Kota pada Menteri Sosial dan Gubernur. Dokumen yang diterima oleh Gubernur dari Kabupaten/Kota dilaporkan pada Menteri Sosial. Dokumen tersebut paling 
lambat diterima oleh Menteri Sosial pada tanggal 15 Oktober dalam tahun berjalan (Sumber: Buku Pedoman Umum Subsidi Rastra 2017).

\section{METODE PENELITIAN}

\subsection{Jenis Penelitian}

Jenis penelitian yang digunakan adalah kualitatif, menurut Sukardi (2013 : 19) penelitian kualitatif adalah penelitian berdasarkan mutu atau kualitas dari tujuan sebuah penelitian itu. Penelitian kualitatif merupakan penelitian yang didesain secara umum untuk objek kajian yang tidak terbatas dan tidak menggunakan metode ilmiah menjadi patokan. Data kualitatif berupa bahan keterangan dalam bentuk uraian kata-kata dan tidak diukur dalam skala numerik. Penelitian ini menggunakan jenis penelitian deskripstif dengan menggumpulkan data-data penelitian yang diperoleh dari Perum Bulog Divre Sulawesi Utara dan Gorontalo.

\subsection{Waktu dan Tempat Penelitian}

Penelitian ini dilaksanakan pada Kantor Perusahaan Umum Badan Usaha Logistik (Perum Bulog) Divisi Regional Provinsi Sulawesi Utara dan Gorontalo, yang bertempat di J1 DiPonegoro, Lawangirung, Wenang Kota Manado, Sulawesi Utara. Waktu dalam penelitian ini dimulai dari April 2018 sampai dengan Mei 2018.

\subsection{Prosedur Penelitian}

Mengidentifikasi masalah, menentukan objek penelitian, menyusunan proposal penelitian, mengumpulkan data, menganalisis dan mengolah data, membuat hasil penelitian, membuat kesimpulan dan memberikan saran.

\subsection{Metode Analisis}

Metode analisis yang digunakan dalam penelitian ini yaitu metode analisis deskripstif yang merupakan metode pembahasan permasalahan yang sifatnya menggunakan, menggambarkan dan membandingkan suatu data atau keadaan dan menerangkan suatu keadaan sedemikian rupa sehingga dapat ditarik kesimpulan. Untuk menganalisis perlakuan akuntansi atas pengelolaan beras sejahtera yang meliputi:

1. Pengakuan dalam pengelolaan atas beras sejatera pada Perum Bulog Divre Sulawesi Utara dan Gorontalo.

2. Pengukuran atas beras sejahtera pada Perum Bulog Divre Sulawesi Utara dan Gorontalo.

3. Penyajian atas pengelolaan beras sejahtera pada Perum Bulog Divre Sulawesi Utara dan Gorontalo.

4. Pengungkapan atas pengelolaan beras sejahtera pada Perum Bulog Divre Sulawesi Utara dan Gorontalo.

Penelitian ini juga membutuhkan dokumen yang perlu dianalisis dalam pengumpulan data yang berkaitan dengan sistem dan prosedur pelaksanaan pendistribusian program bera sejahtera pada Perum Bulog Divre Sulawesi Utara dan Gorontalo.

\section{HASIL ANALISIS DAN PEMBAHASAN}

\subsection{Hasil analisis}

\subsubsection{Mekanisme Pelaksanaan Program Rastra dan Administrasi Pembayaran}

1. Pelaksanaan penyaluran Rastra sampai TD menjadi tugas dan tanggung jawab Perum BULOG.

2. Penyediaan beras untuk KPM Rastra dilakukan oleh Perum BULOG dalam kemasan berlogo Perum BULOG dengan kuantum $10 \mathrm{~kg} / \mathrm{karung}$.

3. Rencana dalam menyalurkan serta menjamin kelancaran proses penyaluran Rastra, Perum BULOG bersama Tim Koordinasi Rastra menyusun rencana penyaluran bulanan sesuai dengan SPA.

4. Mekanisme Penyaluran: 
a. Berdasarkan Pagu Rastra, Bupati/Walikota/Ketua Tim Koordinasi Rastra Kabupaten/Kota ataupun Pejabat yang ditunjuk Bupati/Walikota menerbitkan SPA pada Perum BULOG.

b. Sesuai dengan SPA, Perum BULOG melakukan penerbitan SPPB/DO beras pada tiap-tiap kecamatan atau desa/kelurahan dengan/tanpa menunggu peluncuran resmi penyaluran Rastra pada awal tahun.

c. Berdasarkan SPPB/DO, maka Perum BULOG menyalurkan beras sampai ke TD, termasuk di dalamnya apabila terjadi penggantian beras.

d. Sebelum melakukan penyaluran, dapat dilakukan pengecekan kualitas beras oleh Tim Koordinasi Rastra/Pelaksana Distribusi di Gudang Perum BULOG. Hal ini dibuktikan dengan Berita Acara yang ditandatangani oleh Perum BULOG dan Tim Koordinasi Rastra Kabupaten/Kota/Kecamatan/Pelaksana Distribusi.

e. Serah terima beras antara Perum BULOG bersama dengan Tim Koordinasi Rastra/Pelaksana Distribusi dilakukan di TD serta dibuat BAST yang ditandatangani oleh kedua belah pihak tersebut.

f. Pada dasarnya, penyaluran Rastra dilakukan setiap bulan. Apabila terdapat kebijakan daerah dan/atau kendala antara lain musim panen, kondisi geografis, iklim/cuaca, dan hambatan transportasi, sehingga penyaluran Rastra tidak mungkin dilakukan secara rutin setiap bulan di suatu wilayah, maka penyaluran Rastra bisa diatur lebih lanjut lagi dalam Juklak/Juknis oleh pemerintah daerah setempat.

\subsubsection{Perlakuan Akuntansi atas Pengelolaan Beras Rastra}

Perlakuan akuntansi atas pengelolaan beras rastra pada Perusahaan Umum Badan Usaha Logistik Divisi Regional Provinsi Sulawesi Utara dan Gorontalo, yaitu sebagai berikut:

a. Pengakuan

Pengakuan dalam pengelolaan atas Rastra di Perum Bulog Divre Sulawesi Utara dan Gorontalo yaitu pada saat diterbitkan DO/SPPB atau surat perintah tertulis yang dikeluarkan oleh Perum Bulog untuk menyalurkan beras, Bulog mencatat sebagai piutang atas penjualan rastra pada saat Pemerintah dalam hal ini Kementerian Sosial melunasi piutangnya, Bulog menghapus piutang dan mencatat sebagai pendapatan.

b. Pengukuran

Pengukuran atas pengelolaan beras sejahtera pada Perum Bulog Divre Sulawesi Utara dan Gorontalo diukur berdasarkan pagu rastra atau jumlah beras yang dialokasikan bagi keluarga sasaran penerima manfaat untuk tingkat nasional, provinsi atau kabupaten/kota pada tahun berjalan.

c. Penyajian

Dalam penyajian atas pengelolaan beras sejahtera pada Perum Bulog Divre Sulawesi Utara dan Gorontalo disajakan dalam laporan keuangan yang dicatat dalam laporan laba rugi sebagai pendapatan.

d. Pengungkapan

Selain disajikan dalam laporan laba rugi pengungkapan atas transakasi penjualan rastra dicatat juga dalam neraca. Pengungkapan atas transaksi penjualan rastra di Perum Bulog Divre Sulawesi Utara dan Gorontalo, juga harus diungkapan sedemikian rupa dalam Catatan atas Laporan Keuangan sehingga dapat memberikan informasi yang relevan mengenai bentuk dari pengelolaan atas transaksi beras sejahtera yang diterima atau dikeluarkan. 


\subsection{Pembahasan}

\subsubsection{Analisis Sistem Dan Prosedur Pelaksanaan Pendistribusian Program Rastra di Perum Bulog Divre Sulawesi Utara dan Gorontalo}

Mekanisme pendistribusian beras sejahtera di Perum Bulog Divre Sulawesi Utara dan Gorontalo, dalam pelaksanaanya dimulai dengan perencanaan penetapan pagu rastra ditingkat nasional sampai dengan tingkat desa/kelurahan/kecamatan yang sesuai dengan Rumah Tangga Sasaran Penerima Manfaat yang telah ditentukan untuk mendapatkan bantuan beras sejahtera, penetapan Titik Distribusi atau tempat penyerahan beras sejahtera antara Satker Rastra dan kepala pelaksanaan distribusi rastra yang ditetapkan dikantor desa/kelurahan/kecamatan. Pendistribusian rastra berdasarkan penerbitan SPA dari PemKab/Pemkot untuk Kadivre sesuai pagu dan rincian dari masing-masing desa/kelurahan/kecamatan yang akan didistibusi ke TB lewat penerbitan SPPB/DO Satker Rastra yang telah ditugaskan untuk mengambil beras dari Gudang Bulog yang akan diangkut dan diserahkan kepada kepala pelaksanaan distribusi di TD.

Penyerahan beras sejahtera di TD diisi dalam BAST, pelaksanaan penjualan beras sejahtera dibuat daftar pembayaran harga beras sesuai model DPM-2 dan ditanda tangani oleh kepala pelaksanaan distribusi yang atas mengetahui oleh kepala desa/lurah. Satker rastra membuat rekapitulasi BAST yang ada disetiap tingkat kecamatan dituangkan dalam model MBA-0 dan ditanda tangani oleh satker rastra dan pejabat kecamatan. Pembuatan rekapitulasi MBA-0 oleh Perum Bulog untuk setiap kota/kabupaten sesuai MBA-1 dan ditanda tangani Kadivre/Kasubdivre dan Bupati/Walikota. Rekapitulasi ditingkat divre berdasarkan MBA-1 sesuai format MBA-2 untuk dikirim langsung ke kantor Pusat Bulog di divisi Perbendaharaan.

Adapun kendala-kendala yang terjadi pada saat pendistribusian beras sejahtera dinilai dari berbagai proses, mulai proses pendistribusian maupun proses pencatatan. Dalam proses pendistribusian beras rastra tidak sampai ke keluarga penerima manfaat karena salah sasaran yang disebabkan oleh tim kerja yang telah ditugaskan, yang biasanya masih memengang prinsip kekeluargaan yang penerimanya dibagiakan hanya kepada anggota keluarga atau kenalannya. Pembagian beras bersubsidi kurang tepat sasaran karena penerimanya dari kalangan keluarga yang cukup mampu atau berpendapatan menengah ke atas dengan kata lain bahwa beras sejahtera lebih banyak diterima oleh keluarga bukan miskin dan pagu rastra yang kadang lama dikeluarkan atau surat perintah alokasi mengalami keterlambatan pengajuan ke Bulog. Permasalahan yang sering terjadi dalam proses pencatatan harga tebus rastra penyetor kadang lupa mencantumkan nama desa, sering juga penyetor membayar dengan menyicil sehingga penyulitkan bagian akuntansi dalam pencatatan rastra. Berdasarkan kendala yang terjadi akan berdampak pada pelaporan pihak Bulog pada saat Tim Audit memeriksa laporan keuangan yang terkait dengan pengelolaan beras sejahtera sehingga memperlambat Bulog untuk mempertanggungjawabkan laporan keuangan dikarenakan kendala yang terjadi memperlambat proses pendistrubusian.

\subsubsection{Analisis Perlakuan Akuntansi atas Pengelolaan Beras Sejahtera Pada Perusahaan Umum Badan Usaha Logistik Provinsi Sulawesi Utara dan Gorontalo}

Berdasarkan hasil penelitian yang telah dilakukan di Perum Bulog Divre Sulawesi Utara dan Gorontalo bahwa Perlakuan Akuntansi atas Pengelolaan Beras Sejahtera disusun mengacu pada Standar Akuntansi Keuangan yang diatur dalam peraturan Direksi No. PD08/DK300/08/2013 tentang Kebijakan Akuntanis di Lingkungan Perusahaan Umum (Perum Bulog). Laporan Keuangan Perum Bulog disusun berdasarkan Asumsi Kelangsungan Usaha atau standar yang berbasis akrual dimana pengukuran aset, kewajiban, pendapatan dan beban diakui pada saat periode terjadinya transaksi. Perlakuan Akuntansi atas Pengelolaan Beras Sejahtera pada Perum Bulog Divre Sulawesi Utara dan Gorontalo meliputi pengakuan, 
pengukuran, penyajian dan pengungkapan. Pengakuan dalam pengelolaan Beras Sejahtera yaitu diakui pada saat peneribitan DO atau Perum Bulog mengeluarkan surat perintah tertulis untuk penyaluran beras, penjualan Rastra dicatat sebagai piutang, pada saat Pemerintah dalam hal ini Kementerian Sosial melunasi piutang Rastra, bulog mencatat sebagai pendapatan.

Dalam pengukuran atas pengelolaan rastra diukur berdasarkan pagu rastra atau jumlah beras yang dialokasikan bagi keluarga sasaran penerima manfaat untuk tingkat nasional, provinsi atau kabupaten/kota pada tahun berjalan. Penyajian dalam perlakuan akuntansi atas penggelolaan beras sejahtera, disajikan dalam laporan laba rugi dicatat sebagai pendapatan atas penjualan beras sejahtera disamping itu diungkapkan sedemikian rupa pada Catatan atas Laporan Keuangan sehingga dapat dijelaskan dan dapat memberikan informasi yang relevan bentuk pencatat dari pendapatan yang diterima atau yang dikeluarkan oleh Perum Bulog Divre Sulawesi Utara dan Gorontalo. Adapun pencatatan perlakuan akuntansi atas pengelolaan beras sejahtera pada Perum Bulog Divre Sulawesi Utara dan Gorontalo, yaitu sebagai berikut :

a. Jurnal atas pembayaran beras sejahtera untuk masyarakat dari pemerintah

\begin{tabular}{|c|c|c|}
\hline Nama Akun & Debet & Kredit \\
\hline Selisih Harga & xxx & - \\
\hline Perjualan rastra & - & xxx \\
\hline
\end{tabular}

b. Jurnal untuk transfer ke kantor Bulog Pusat

\begin{tabular}{|c|c|c|}
\hline Nama Akun & Debet & Kredit \\
\hline Rekening Antar Kantor & $\mathrm{xxx}$ & - \\
\hline Bank & - & $\mathrm{xxx}$ \\
\hline
\end{tabular}

\section{KESIMPULAN DAN SARAN}

\subsection{Kesimpulan}

Berdasarkan hasil penelitian mengenai Perlakuan Akuntansi atas Pengelolaan Beras Sejahtera pada Perum Bulog Divre Sulawesi Utara dan Gorontalo, maka penulis menarik kesimpulan yang terkait dengan hasil penelitian, yaitu sebgai berikut :

1. Perlakuan akuntansi dalam hal ini meliputi pangakuan, pengukuran, penyajian dan pengungkaan atas Pengelolaan Beras Sejahtera pada Perum Bulog Divre Sulut dan Gorontalo yang menyajikan laporan keuangan disusun berdasarkan aturan Kebijakan Akuntansi Bulog yang mengacu pada PSAK 01 sebagai acuan dasar penyajian laporan keuangan yang di atur dalam peraturan direksi nomor : PD-08/DK300/08/2013 tentang kebijakan akuntansi di lingkungan perum bulog yang berbasis akrual.

2. Mekanisme pelaksanaan pendistrubusian beras sejahtera pada Perum Bulog Divre Sulawesi Utara dan Gorontalo sudah terlaksana cukup baik dan karena berjalan sesuai dengan proses yang telah ditentukan, meskipun masih terjadi beberapa kendala yang menghambat proses pendistribusian beras sejahtera. Faktor-faktor yang sering terjadi dalam proses pendistribusian beras sejahtera yang menjadi kendala yaitu, belum tepatnya penerima rastra karena tidak tepat sasaran yang disebabkan oleh petugas pembagian ditingkat desa/kelurahan yang masih memegang prinsip kekeluargaan sehingga masyarakat yang tergolong mampu ada yang mendapat jatah beras sejahtera. Pagu rastra yang kadang terlambat dikeluarkan sehingga berdampak pada keterlambatan pendistribusian masyarakat.

\subsection{Saran}

Berdasarkan analisa data yang telah dibahas sebelumnya,beberapa saran dapat diberikan dalam penelitian ini, antara lain: 
1. Bagi Perum Bulog Divre Sulawesi Utara dan Gorontalo tetap berpedoman terhadap standar yang berlaku dalam laporan keuangan sehingga perlakuan akuntansi atas pengelolaan beras sejahtera tetap berjalan baik.

2. Perum Bulog sebaiknya tetap mempertahankan efektifitas dan eksistensi dalam melakukan pendistribusian beras sejahtera agar mengurangi kendala-kendala yang sering terjadi.

\section{DAFTAR PUSTAKA}

Basuki, Arief. 2013. Analisis Pengaruh Cash Ratio, Debt to Total Assets Ratio, Debt to Equity Ratio, Return On Assets dan Net Profit Margin Terhadap Dividen Payout Ratio Pada Perusahaan yang Listing di Bursa Efek Indonesia Periode 2007-2011. Jurnal Semarang. Universitas Diponegoro.

Bulog. 2018. http://www.bulog.co.id/sekilasraskin.php. 26 April 2018 (21.30).

Ganuwiara, Tewe. 2018. Pelaksanaan Distribusi Raskin Di Perum Bulog Divisi Regional 1 Bandung. $\quad$ https://www.scribd.com/doc/99780837/PELAKSANAAN-DISTRIBUSIRASKIN-DI-PERUM-BULOG-SUB-DIVISI-REGIONAL-I-BANDUNG . 26 April 2018 (21.15).

Hery. 2013. Akuntansi Dasar 1 Dan 2 PT Gramedia Widia Sarana Indonesia. Jakarta.

Pedoman Umum Rastra. 2017. https://www.kemenkopmk.go.id. 20 Juni 2018 (21:45)

Peraturan Menteri Keuangan Nomor 125 Tahun 2010 Subsidi Beras bagi Masyarakat Berpendapatan Rendah. Berita Negara Republik Indonesia Tahun 2010 Nomor 332. Jakarta.

Purnama, B.E.P. 2010. Pembangunan Sistem Informasi Pendapatan Rakyat Miskin Untuk KecamatanKebonanjung Kabupaten Pacitan. Journal Speed : Universitas Surakarta.

Sukardi. 2013. Metodologi Penelitian Pendidikan Kompetensi dan Praktiknya, Jakarta: Penerbit Bumi Aksara.

Tanor, Melissa. 2015. Analisis Laporan Graha Internasional Keuangan Dalam Mengukur Kinerja Keuangan Pada PT. Bank Artha TBK. Jurnal EMBA Universitas Samratulangi Manado.

Tinungki, Angelina. 2014. Penerapan laporan Keuangan Organisasi Nirlaba Berdasarkan PSAK no. 45 pada panti Sosial Tresna Werdha Hana. Jurnal EMBA Universitas Samratulangi, Vol.2, No 2.

Wiratna, P.E.S. DKK. 2015. Perlakuan Akuntansi Pendapatan Dan Beban Terhadap Kewajaran Laporan laba Rugi. E-journal S1 Ak. Universitas Pendidikan Ganesa. Bali.

Wikipedia. 2017. Subsidi. https://id.m.wikipedia.org/wiki/subsidi. 26 April 2018 (19:45). 